\title{
PHOTOSYNTHESIS AND LEAF NITROGEN IN FIVE AMAZONIAN TREE SPECIES DURING EARLY SECONDARY SUCCESSION ${ }^{1}$
}

\author{
D. S. ELLSWORTH ${ }^{2}$ \\ Department of Forestry, University of Wisconsin, Madison, Wisconsin 53706 USA \\ P. B. REICH \\ Department of Forest Resources, University of Minnesota, St. Paul, Minnesota 55108 USA
}

\begin{abstract}
Field measurements of maximum net photosynthesis $\left(P_{\max }\right)$, leaf nitrogen $(\mathrm{N})$ content (leaf $\mathrm{N}$ per area and percent $\mathrm{N}$ ), and specific leaf area (SLA) were made for Amazonian tree species within and across early successional sites of known ages after abandonment from slash-and-burn agriculture. We examined five species across a successional sere near San Carlos de Río Negro, Venezuela, to test whether plasticity was associated with successional status and to determine whether changes in foliar properties during secondary succession can be attributed to shifts in species composition, in resource availability, or both. Average leaf $\mathrm{N}$ concentration was high (nearly $3 \%$ ) for a pioneer species (Cecropia ficifolia) early in succession (1-3 yr after abandonment) but was always lower for the other early and mid- to-late succession species, especially later in succession (1-2\% at 5-10 yr after abandonment). Net photosynthetic capacity $\left(P_{\max } /\right.$ area and $P_{\max } /$ mass) varied as much as sixfold, being higher in pioneer species such as Cecropia and Vismia on recently abandoned sites and lower in late successional species such as Miconia and Licania on 10-yr abandoned agricultural sites. Total daily light availability also varied widely (14-fold) from its peak $1 \mathrm{yr}$ after farm abandonment to low levels $9 \mathrm{yr}$ into succession.

During the first $5 \mathrm{yr}$ of secondary succession, there were significant $(P<0.05)$ differences in $P_{\max }$ and leaf $\mathrm{N}$ concentration among species in any given year. In most species, $P_{\max }$ values declined with increasing time since abandonment within any given site. There were important differences in photosynthetic plasticity among species: $P_{\max }$ tended to be much greater in earlier than later successional species soon after abandonment. Also, the difference in $P_{\max }$ among species narrowed (or reversed) over time since abandonment, largely because of decreasing $P_{\max }$ in pioneer species. The results suggest that changes in both species composition and in resource availability combine to produce the common pattern of decreasing leaf $\mathrm{N}$ concentration and photosynthetic rates during early rain forest succession after agriculture.

Early successional species showed strong $\left(r^{2} \geq 0.57, P=0.0001\right)$ mass-based photosynthesis-N relationships but weak $\left(r^{2}=0.40\right.$ or lower, $\left.P=0.0001\right)$ area-based relationships both across the secondary successional sere after agriculture and across sites varying in types of disturbance. Both mass- and area-based photosynthesis- $\mathrm{N}$ relationships were poorer or not significant $(P>0.05)$ for mid- to late-successional species. Higher instantaneous $P_{\max } / \mathrm{N}$ and greater slopes of the photosynthesis-N relationships in early than late successional species suggest that pioneer species may show greater carbon assimilation capacity with elevated leaf $\mathrm{N}$ concentration on early successional sites than co-occurring species. The data suggest that early and late successional species may differ in the mode and degree of leaf-level physiological plasticity across succession.
\end{abstract}

Key words: light; nitrogen; photosynthesis, rain forest trees; secondary succession; tropical succession.

\section{INTRODUCTION}

Distinct patterns in the successional dynamics of species dominance following disturbance have long been recognized (Cooper 1926) and have frequently been associated with patterns in resource availability (Tilman 1988). While the role of key resources such

\footnotetext{
'Manuscript received 31 March 1995; revised 3 April 1995; accepted 6 July 1995.

${ }^{2}$ Present address: School of the Environment, P.O. Box 90328, Duke University, Durham, North Carolina 27708 USA.
}

as light and nutrients have been considered paramount in secondary succession following anthropogenic disturbance, species may both alter and respond to the availability of these resources as they vary over successional time scales (Vitousek and Walker 1987, Tilman and Wedin 1991). There is a considerable theoretical framework suggesting that plant species characteristic of early successional habitats have contrasting physiological and life history traits compared to species from later successional habitats (Bazzaz 1979, Bazzaz and Pickett 1980), which is generally consistent with patterns in the availability of light and nutrients 
through succession (Huston and Smith 1987). Although these relationships have been well elucidated for plants grown in constant or controlled environments (i.e., Björkman 1981, Oberbauer and Strain 1984, StraussDebenedetti and Bazzaz 1991), we know much less about such relationships in natural environments.

Within the constraints of intrinsic morphological and physiological traits, the ability of a given species to grow in the face of changing resource availability during succession may depend on its physiological plasticity. To remain competitive and dominant on a site during succession, species must be capable of altering functional traits that maximize physiological performance during succession (Schulze and Chapin 1987). Although it has been hypothesized that plasticity in photosynthetic traits may be associated with differences in successional status among temperate species (Bazzaz 1979, Bazzaz and Carlson 1982), there is growing evidence from tropical studies indicating that early successional species are not necessarily more flexible in this regard compared to later successional species (Oberbauer and Strain 1984, Thompson et al. 1988, Chazdon 1992, Clark and Clark 1992). Comparisons of gap-phase successional species in tropical forests have found considerable within-species plasticity in leaf photosynthesis in many woody species, regardless of the light availability characteristic of their typical habitat (Chazdon and Field 1987, Walters and Field 1987, Chazdon 1992, Thompson et al. 1992). However, to our knowledge there has been no systematic analysis of adjustments in species photosynthetic capabilities across a successional chronosequence in human-disturbed tropical ecosystems or with reference to the changes in light and soil resources that are coincident with early succession after agriculture (Uhl et al. 1982a, Vitousek and Walker 1987). Because canopy development and hence shading progresses rapidly during early tropical succession (Ewel et al. 1981, Brown and Lugo 1990), and site nutrient availability also typically shows large changes at that time (Vitousek et al. 1989, Ewel et al. 1991), it is important to understand the physiological responses of tropical species to environmental variation during early secondary succession (Mooney et al. 1984). Such information is critical to understanding patterns in forest recovery following human-induced disturbance.

In the last two decades, large areas of the Amazon Basin have been cleared for agriculture (Houghton et al. 1991). However, much of this land is abandoned after a short period of land use (Brown and Lugo 1990). In this paper we describe a study of field photosynthetic performance, leaf structure, nutrient content, and their plasticity in five tree species common during secondary succession in the upper Río Negro region of the Amazon Basin (Uhl 1987, Reich et al. 1995). Based on 10 $\mathrm{yr}$ of data from an adjacent site (Uhl 1987; C. Uhl, unpublished data), these five species can be characterized according to the time in secondary succession at which they are most common, ranging from 1-2 yr to $\geq 10 \mathrm{yr}$ after abandonment (see Methods: Study site and species descriptions below). The present study complements earlier studies of seed dispersal, seedling establishment, tree abundance, and growth and biomass accumulation for the study species on secondary successional sites adjacent to those used in our study (Uhl et al. 1982a, Uhl and Jordan 1984, Uhl 1987), and represents one of the best characterized secondary successional seres in a tropical rain forest. Although patterns of early plant community succession may be determined by differential seed dispersal, germination, and seedling establishment among species (Pickett et al. 1987), differences in physiological and morphological traits, and their plasticity with respect to resources during succession, can indicate differential abilities of co-occurring species to use and compete for limiting resources during succession (Chapin et al. 1987, Tilman 1988). Thus we concentrated our analysis on leaf photosynthetic traits and plasticity during succession in relationship to other key leaf traits such as leaf nutrient concentration (an indication of plant and site nutrition) and specific leaf area (SLA, an index of leaf structural density).

We hypothesized that there would be differences in leaf photosynthetic traits among tropical species that are most common at different stages along an early successional sequence after slash-and-burn agriculture. Since most plant species are capable of some degree of physiological, morphological and/or allocational alterations to improve acquisition of limiting resources for growth and biomass accumulation (Chapin et al. 1987, Schulze and Chapin 1987), we also expected plasticity in leaf traits within any given species that occurs along such a sere. We hypothesized that individual species would show significant differences in $P_{\text {max }}$, SLA, leaf nitrogen concentration, and photosynthetic nitrogen-use efficiency across successional stages that vary in resource levels, and that different species would show different degrees of plasticity in response to changing resource levels depending on their successional status (Bazzaz 1979, Björkman 1981).

\section{METHODS}

\section{Study site and species descriptions}

The research was carried out near the village of San Carlos de Río Negro $\left(1^{\circ} 56^{\prime} \mathrm{N}, 67^{\circ} 03^{\prime} \mathrm{W}\right.$; $120 \mathrm{~m}$ elevation), a remote location in Venezuela's Amazon Territory. The climate at San Carlos is wet equatorial with a relatively aseasonal pattern of temperature and precipitation. Mean annual temperature is $26^{\circ} \mathrm{C}$, annual precipitation averages $3500 \mathrm{~mm}$, and mean monthly precipitation exceeds $200 \mathrm{~mm}$ in every month of the year (Estación de Hidrología, San Carlos de Río Negro, Ministerio del Ambiente y de Recursos Naturales Renovables, unpublished data).

The study sites were located $4-5 \mathrm{~km}$ east of San 
Carlos in lowland tierra firme forest in the gently rolling terrain (20-40 $\mathrm{m}$ above mean river level). The local tierra firme forest is an evergreen rain forest $20-30 \mathrm{~m}$ in height. Tierra firme forests occur on relatively welldrained, highly weathered Oxisols and Ultisols covered by a thin cap of sand $<50 \mathrm{~cm}$ deep (Medina and Cuevas 1989). These are the only soils used locally for agriculture. Tierra firme soils of the upper Río Negro basin are acid ( $\mathrm{pH} \approx 4$ ), nutrient-poor, and composed of highly weathered clays with high $\mathrm{Fe}$ and $\mathrm{Al}$ concentrations and very low cation-exchange capacity (Fittkau et al. 1975, Herrera et al. 1978). Aspects of the nutrient dynamics and nutrient limitations in the primary forest communities near San Carlos are summarized in Medina and Cuevas (1989) and Reich et al. (1994).

The study focused on sites abandoned from slashand-burn agriculture, the most common anthropogenic disturbance in the upper Río Negro region (Clark and Uhl 1987). Postagricultural successional sites were all located within $0.5 \mathrm{~km}$ of each other near a large undisturbed tierra firme forest tract. Sites were selected for traditional agriculture and cut, burned, and farmed by an experienced local farmer. On each site, $\approx 0.5$ ha of forest was cut in September-November and burned in December-March (Clark and Uhl 1987). Manioc (Manihot esculenta Crantz) is by far the most abundant crop planted on these sites. Farm sites were weeded occasionally and the resulting plant residue was burned in slash piles on the site. Abandonment from active agriculture occurred $\approx 2$ yr after burning, mainly because of declining crop yields (Uhl et al. 1982a).

The study was conducted on three postagricultural sites representing 1,3 , and 9 yr after abandonment in 1988 (referred to as Sites 1, 2, and 3, respectively). Three to five study trees of each species (when present) were selected at each site. Leaf physiology was subsequently followed for the same marked trees on each site for either 2 or $3 \mathrm{yr}$, providing early successional seres from 1 to 3, 3-5, and 9-10 yr after abandonment. Species on an additional site at $2 \mathrm{yr}$ after abandonment were also measured, but only in a single year. Whenever a study species was present and located on a site it was included in the study design. In order to contrast extremes in disturbance regimes, we also studied 3-4 individuals of the successional trees Vismia japurensis Reichardt and Miconia dispar Bentham that were present in a tierra firme treefall gap $\left(\approx 200 \mathrm{~m}^{2}\right.$ in area) 2 yr after formation (cf. Uhl et al. 1988) and on a highly degraded, bulldozed site 10 yr after disturbance (Uhl et al. 1982b). Besides a number of herbaceous and graminoid species, only scattered, short trees $(<2 \mathrm{~m}$ tall) of one species (Vismia) were present on the bulldozed site $10 \mathrm{yr}$ after disturbance.

Study species were chosen based on previous studies of their successional ecology and abundance on disturbed sites (Uhl 1987, Uhl et al. 1988). Cecropia ficifolia Snethlage is a short-lived, fast-growing early successional pioneer that colonizes agricultural sites before abandonment from agriculture and persists for 3-5 yr. Vismia colonizes early successional postagricultural sites and forms the dominant canopy in stands 2-5 yr after abandonment. Bellucia grossularioides (L.) Triana is longer lived and later successional than the previous two species and is frequently found with Vismia on early successional sites in low densities. $M i$ conia dispar is a common small-gap colonizer that also establishes under early successional trees on postagricultural sites. Melastomataceous trees (including $\mathrm{Mi}$ conia spp.) form the dominant subcanopy and canopy of postagricultural sites at 10-15 yr after abandonment. Both Miconia and Vismia were also abundant in the tierra firme treefall gap used in this study. Licania heteromorpha Bentham is abundant in both the canopy and understory of undisturbed and late successional tierra firme forests and may colonize postagricultural sites between 6 and $10 \mathrm{yr}$ after abandonment. In order to interpret our measurements with respect to perceived species successional strategies, the successional status of each species will be defined as in Reich et al. (1995) according to the time after abandonment when each species is most common. Cecropia is a pioneer species, Vismia is the next earliest successional, followed by Bellucia and the mid-to-late successional species $\mathrm{Mi}$ conia and Licania. Species are ranked by successional status in tables and figures (e.g., earlier successional species are listed first).

\section{Physiological measurements}

We measured gas exchange for young, fully expanded leaves of naturally occurring plants in the field during January and February in three consecutive years. Measurements were made on $\approx 6-20$ leaves per tree in midto upper-crown positions of trees $\leq 6 \mathrm{~m}$ in height (or at the top of the crown for the unbranched tree Cecropia). Dominant trees of Cecropia, Vismia, and Bellucia were randomly selected for measurements on all sites (when present). Miconia and Licania only occurred as saplings $<4 \mathrm{~m}$ in height beneath a canopy of the early successional species. Vismia was not measured on sites beyond $5 \mathrm{yr}$ after abandonment because of the high mortality of this species on those sites (C. Uhl, unpublished data). All five species are evergreen but vary in leaf life-span (Reich et al. 1991); hence, measurements for each species were taken on young mature leaves at the nodal position corresponding to the age of peak physiological capacity (Reich et al. 1991).

Simultaneous measurements of photosynthetic $\mathrm{CO}_{2}$ assimilation and leaf conductance to water vapor were made under ambient conditions with a portable leaf chamber and infra-red gas analyzer (IRGA) operated in the differential mode (ADC model LCA-2, Hoddesdon, Hertsfordshire, England). Measurements in open, successional sites were made at mid- to late-morning (0800-1100 local time) to minimize limiting vapor pressure deficits or excessive temperatures. In shaded understory and gap sites, measurements were made lat- 
er in the day (1100-1400 local time) on foliage located in stable sunflecks for at least $5 \mathrm{~min}$ in an attempt to ensure that photosynthetic induction had already occurred (Pearcy 1988). We present data for leaves measured at above-saturating photosynthetic photon flux density (PPFD) under natural sunlight as determined by photosynthetic light response curves derived from field measurements on a population of leaves measured at different instantaneous PPFD levels (D. S. Ellsworth, unpublished data) using the methodology of Riddoch et al. (1991). Thus, sampling was designed so that measurements were made under nonlimiting environmental conditions to closely reflect leaf photosynthetic capacity at ambient $\mathrm{CO}_{2}\left(P_{\text {max }}\right)$ in the field (Reich et al. 1991).

After $P_{\max }$ was measured, leaves were collected, traced for fresh leaf area determinations, and ovendried to a constant mass at $70^{\circ} \mathrm{C}$. Single--sided leaf areas were measured from the leaf traces with a leaf area meter (LI-3100, LI-COR, Lincoln, Nebraska, USA). Specific leaf area (SLA; in square centimetres per gram) was expressed as the ratio of fresh leaf area to leaf dry mass (excluding the petiole) for all samples. Nutrient analyses were performed by the University of Wisconsin Soil and Plant Analysis Laboratory. Total leaf $\mathrm{N}$ was analyzed colorimetrically after micro-Kjeldahl digestion and other mineral nutrients were determined by plasma-emission spectrometry techniques.

\section{Leaf light environment}

Horizontally mounted quantum sensors (LI-190S, LI-COR, Lincoln, Nebraska, USA) or leaf-mounted gallium-arsenide phosphide photodiodes (Model G1118, Hamamatsu Photonics KK, Hamamatsu, Japan) were used to characterize the light environment of the different successional stages in this study. Leaf-mounted sensors were calibrated against a quantum sensor under metal halide lamps in the laboratory. Quantum sensors were mounted at $1.5 \mathrm{~m}$ in arbitrary locations in each study plot. Data for leaf-mounted sensors on horizontally oriented leaves ranging from 1.5 to $1.7 \mathrm{~m}$ in height were also analyzed for this purpose. Sensors were monitored at 5-s intervals and summed to provide daily estimates of PPFD.

\section{Statistical analyses}

Data from the four leaves for each tree and site-year combination exhibiting the highest net photosynthetic rates (on a mass basis) were used in all statistical analyses to ensure that the field measurements closely reflected $P_{\max }$ for each species in the specific habitat. Photosynthetic rates from the larger sample of leaves measured from each individual were $85-95 \%$ of $P_{\max }$. Differences among species on a site using the larger data set were consistent with those shown for the reduced data set. Data were analyzed using a repeatedmeasures analysis of variance (SAS 1994) for each site separately (using only complete combinations of species and years) with species and year as the main ef- fects. When species or species $\times$ year interactions were highly significant $(P<0.01)$ for a site, comparisons between species (within years) and between years were made at $P<0.05$ using Bonferroni's least significant difference test (Steel and Torrie 1980). A randomized model for linear regression was used to analyze relationships among all physiological and leaf traits (SAS 1994). Data were log transformed if heterogeneous error variances were encountered.

\section{RESUlts}

\section{Successional trends in leaf characteristics}

On recently abandoned Sites 1 and 2, net photosynthesis varied by as much as threefold among species and years combined for $P_{\max }$ /area (Fig. 1) and sixfold for $P_{\max } /$ mass (Fig. 2). To clarify differences among species and years, repeated-measures analyses were made for common groupings of species and years (see Table 1). At Sites 1 and 2 (Table 1, Figs. 1 and 2), there were generally significant $(P<0.001)$ differences in $P_{\max }$ among species, $P_{\max }$ rates declined from year to year (1-3 or 3-5, respectively), and there were significant differences in plasticity (interactions between species and year): rates tended to be much greater in earlier than later successional species sooner after abandonment, and the differences between species narrowed (or reversed) with time, largely due to decreasing $P_{\max }$ in early successional species. At Site 3 there were generally consistent differences between species in both years for all leaf traits, but no significant difference between years 9 and 10 .

Photosynthetic rates on a unit mass basis $\left(P_{\max } / \mathrm{mass}\right)$ were always greater in the early successional species Cecropia than in other species (Fig. 2), but the differences narrowed with time. At Site $1, P_{\max }$ /area was greater $(P<0.05)$ in Cecropia than in Vismia and Bellucia in year 1 , but not later in succession (years 2-3), and also not 3-4 yr after abandonment at Site 2. $P_{\max }$ /mass in Vismia was also generally greater $(P<0.05)$ than in the later successional species Bellucia and Miconia at both sites (Fig. 2). Overall differences in $P_{\max } /$ mass among species were smaller later in succession $(\approx 10$ $50 \%$ at 5 and 9-10 yr after abandonment) than earlier (up to $300 \%$ at $1 \mathrm{yr}$ after abandonment). Significant differences $(P<0.05)$ in all leaf parameters were observed between Miconia and Licania in years 9 and/or 10 , with lower $P_{\max }$, leaf $\mathrm{N}$ concentration, and SLA in late successional Licania (Figs. 1 and 2).

At both Sites 1 and 2, leaf $N$ concentration varied $(P$ $<0.05$ ) among species and years, and there were significant species $\times$ year interactions, although the latter explained only a very small portion of the total variation in $\mathrm{N}$ concentration compared to species or year. Differences in leaf $\mathrm{N}$ concentration between species at Site 1 corresponded closely to those for $P_{\max } /$ mass in years 13 (Fig. 2). At both Sites 1 and 2 in all years, percent $N$ $(2.2-2.7 \%)$ and SLA were greater in Cecropia than in 
a. SITE 1
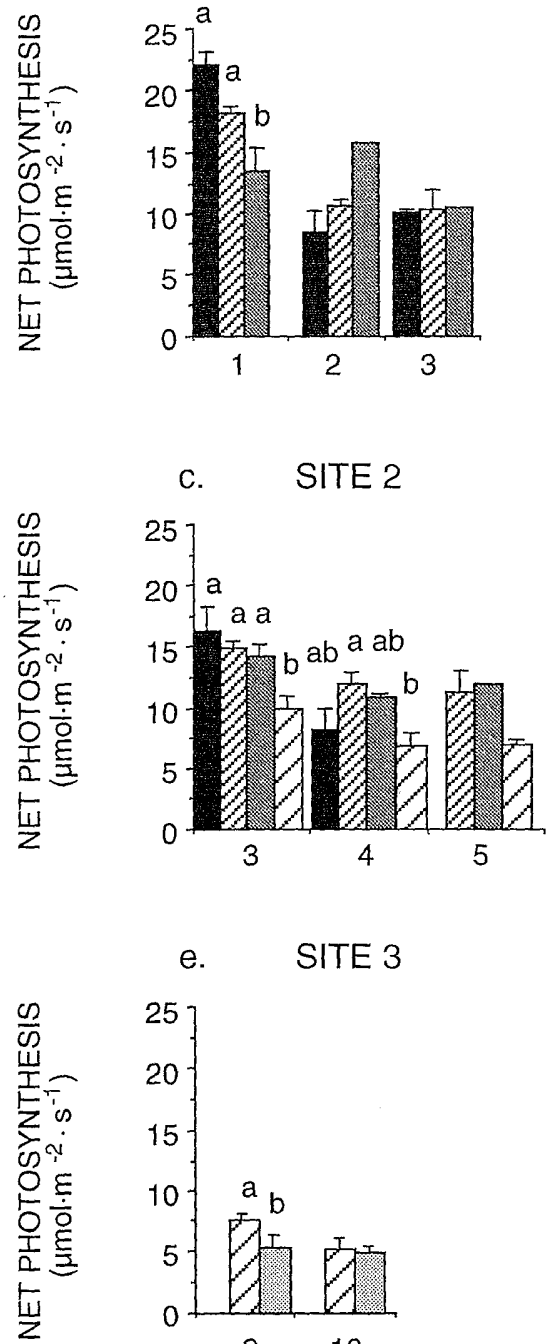

C.

e. SITE 3

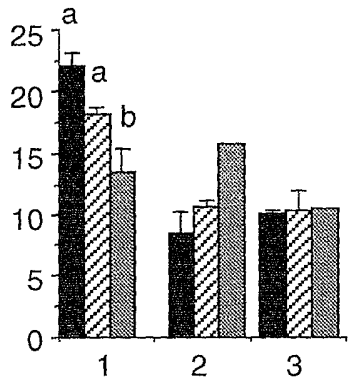

SITE 2

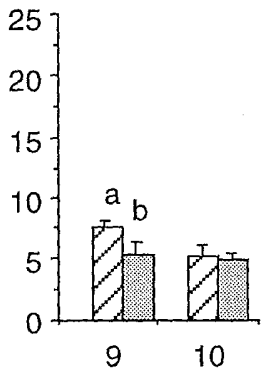

Cecropia

$\square$ Vismia

Bellucia

Q Miconia

Licania

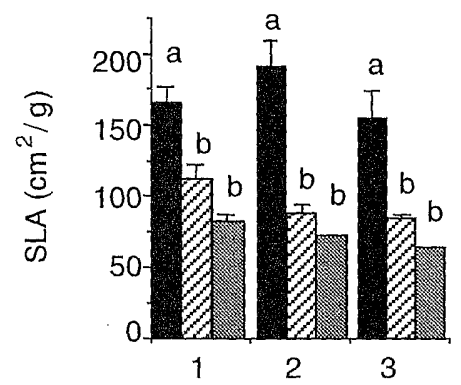

d.

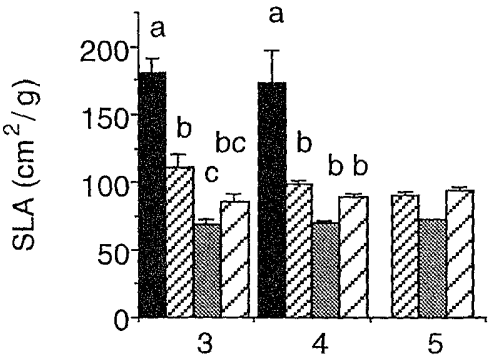

f.

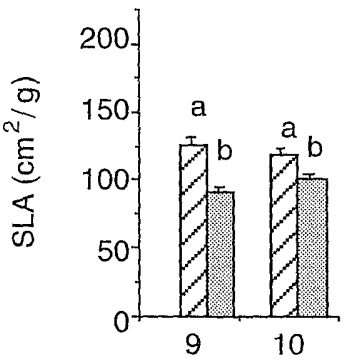

YEARS AFTER ABANDONMENT

Fig. 1. Variation in area-based net photosynthesis $\left(P_{\max } /\right.$ area) and specific leaf area (SLA) in five successional tree species on three sites along a successional chronosequence after slash-and-burn agriculture. (a-b) $P_{\max }$ /area and SLA for Site 1; (c-d) data for Site 2; (e-f) data for Site 3. Each bar represents the mean value for 3-5 trees with 1 SE indicated. For Bellucia, only one individual was measured on Site 1 at 2 and 3 yr. For all other species, if bars are absent, then the species was not present on the site at the time of measurement. Within each site and at a given successional stage (years after abandonment), different letters indicate means that are significantly different $(P<0.05)$ using Bonferroni's test. See Table 1 for overall analysis of variance results. An absence of letters for a site at a given successional stage indicates that the species differences were not significantly different $(P>0.05)$.

the co-occurring species (e.g., percent $\mathrm{N}$ ranged from 1 to $2 \%$ ), which did not vary consistently in these respects.

Photosynthetic capacity (both $P_{\max }$ /area and $P_{\max }$ I mass) and percent $\mathrm{N}$ were significantly greater in $\mathrm{Cec}$ ropia and Vismia at year 1 on Site 1 than all other years on either site where they occurred $(P<0.01)$. Both species showed an overall decreasing trend in $P_{\text {max }} /$ area, $P_{\text {max }} /$ mass, and percent $\mathrm{N}$ in successive years on a given site (Figs. 1 and 2). $P_{\max }$ /mass and percent $\mathrm{N}$ decreased by $\approx 50$ and $25 \%$, respectively, in both species on Site 1 from the 1st to 3rd yr after abandonment (Fig. 2). In contrast, there were weaker or no apparent trends in these characteristics for the melastomataceous trees $\mathrm{Bel}$ lucia and Miconia in years 1-3 or 3-5 of succession, at Sites 1 and 2, respectively. The only significant year-toyear changes in SLA were decreases in Vismia and $\mathrm{Bel}$ lucia from years 1 to 3 at Site 1 (Table 1, Fig. 1). Overall, the above results suggest that changes in both species 
a. SITE 1
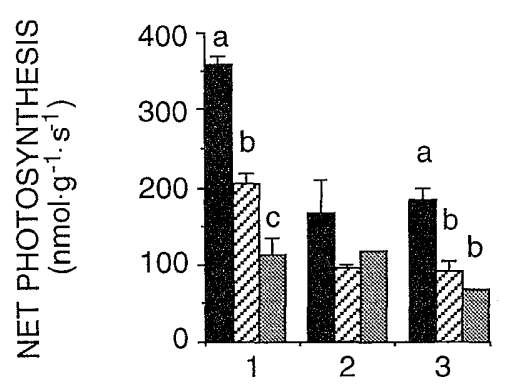

C. SITE 2
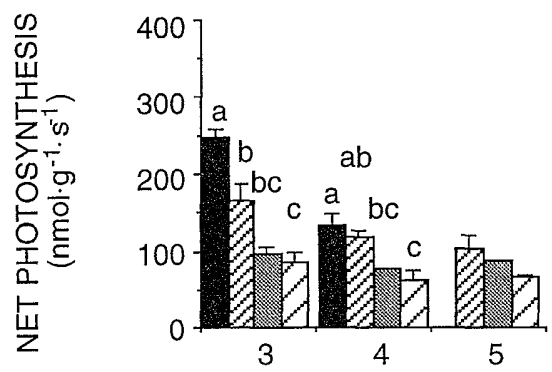

e. SITE 3
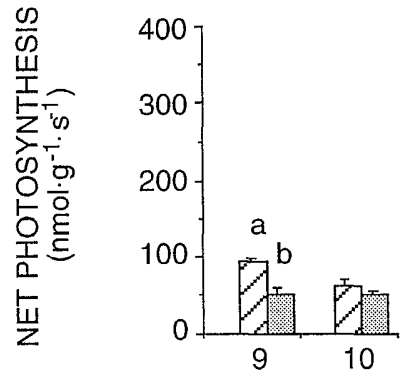

b.

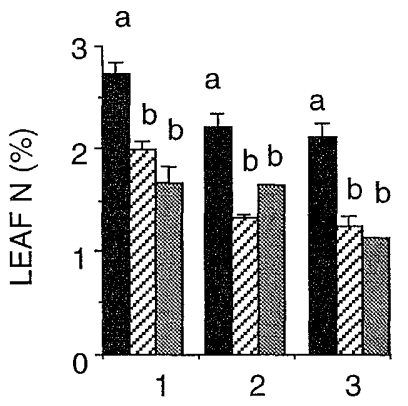

d.

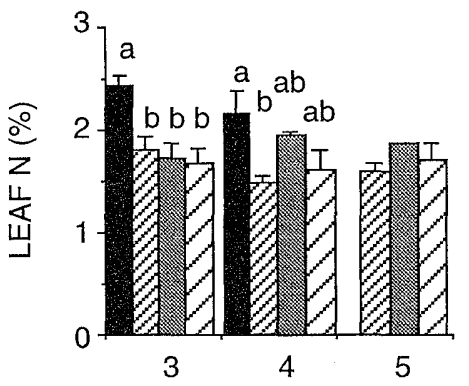

f.

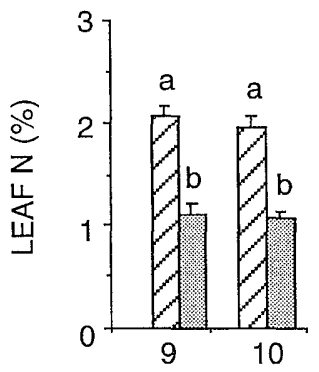

YEARS AFTER ABANDONMENT

FIG. 2. Variation in net photosynthesis on a unit mass basis $\left(P_{\max } / \mathrm{mass}\right)$ and leaf nitrogen concentration (leaf N) among species on three sites along a successional chronosequence. (a-b) $P_{\max } /$ mass and leaf $\mathrm{N}$ concentration data for Site 1 ; (c-d) data for Site 2; (e-f) Site 3. Legend otherwise as in Fig. 1. Within each site and at a given successional stage (years after abandonment), different letters indicate means that are significantly different $(P<0.05)$.

composition and in resource availability combine to cause the pattern of decreasing leaf $\mathrm{N}$ concentration and photosynthetic rates during secondary succession.

Variation in $P_{\max } /$ mass between the study trees on any given site for each species considered separately (average coefficient of variation $=20 \%$, range $4-36 \%$ ) was similar to variation in this parameter among species on a site (average coefficient of variation $=25 \%$ ). Only two successional ages ( 2 and $3 \mathrm{yr}$ after abandonment) were replicated on independent sites in this study. $P_{\max } l$ mass varied by $30-50 \%$ for species on different sites at the same successional stage (Fig. 2a), which is not sur- prising given intrinsic site differences and site patchiness. Both Vismia and Bellucia showed significant differences $(P<0.05)$ in $P_{\max } /$ mass and percent $\mathrm{N}$ between site 1 and site 2 at $3 \mathrm{yr}$ after abandonment (Fig. 2a). Data from a second site measured only at $2 \mathrm{yr}$ after abandonment, however, were not significantly different from those shown in Figs. 1 and 2 for any parameter or species $(P<0.05$, data not shown).

\section{Leaf light environment}

Light availability (both average and total daily PPFD) showed strong decreases as succession pro- 
TABLE 1. Summary of results of repeated-measures analyses of variance.* Mean square errors are shown in the final row of each display.

\begin{tabular}{|c|c|c|c|c|c|c|c|c|}
\hline \multirow[b]{2}{*}{ Variable } & \multicolumn{2}{|c|}{$P_{\max } /$ mass } & \multicolumn{2}{|c|}{$P_{\max } /$ area } & \multicolumn{2}{|c|}{ SLA } & \multicolumn{2}{|c|}{$\% \mathrm{~N}$} \\
\hline & $F$ & $P$ & $F$ & $P$ & $F$ & $P$ & $F$ & $P$ \\
\hline \multicolumn{9}{|c|}{ Site 1. Cecropia, Vismia, and Bellucia contrasted across years $1-3(\mathrm{df}=22)$} \\
\hline Year & 35.1 & 0.0001 & 40.7 & 0.0001 & \multicolumn{2}{|c|}{ NS } & 30.8 & 0.0001 \\
\hline Species & 32.7 & 0.0001 & \multicolumn{2}{|r|}{0.0001} & 60.7 & \multirow[t]{3}{*}{0.0001} & 75.7 & \multirow[t]{3}{*}{0.0001} \\
\hline Year $\times$ species & 4.4 & 0.018 & 7.4 & 0.0024 & & & & \\
\hline Error MS & & & & & & & & \\
\hline \multicolumn{9}{|c|}{ Site 2. Cecropia, Vismia, Bellucia, and Miconia contrasted across years $3-4(\mathrm{df}=26)$} \\
\hline Year & 26.5 & 0.0001 & 28.7 & 0.0001 & & & \multicolumn{2}{|c|}{ NS } \\
\hline Species & 26.9 & 0.0001 & 7.2 & 0.0020 & 30.0 & 0.0001 & 10.7 & 0.0003 \\
\hline Year $\times$ species & 4.4 & 0.016 & \multicolumn{2}{|c|}{ NS } & \multicolumn{2}{|c|}{ NS } & \multicolumn{2}{|c|}{ NS } \\
\hline Error MS & \multicolumn{2}{|c|}{68.03} & \multicolumn{2}{|c|}{4.2} & \multicolumn{2}{|c|}{338.0} & \multicolumn{2}{|c|}{0.056} \\
\hline \multicolumn{9}{|c|}{ Site 2. Vismia, Bellucia, and Miconia contrasted across years $3-5(\mathrm{df}=28)$} \\
\hline Year & 17.8 & 0.0001 & 27.2 & 0.0001 & \multicolumn{2}{|c|}{ NS } & \multicolumn{2}{|c|}{ NS } \\
\hline Species & 6.1 & 0.088 & 11.0 & 0.0006 & 21.6 & 0.0001 & \multicolumn{2}{|c|}{ NS } \\
\hline Year $X$ species & \multicolumn{2}{|c|}{ NS } & & \multicolumn{2}{|c|}{ NS } & \multirow{2}{*}{\multicolumn{2}{|c|}{$\begin{array}{l}\text { NS } \\
\ldots\end{array}$}} \\
\hline Error MS & \multicolumn{2}{|c|}{590.6} & \multicolumn{2}{|c|}{2.79} & \multicolumn{2}{|c|}{100.8} & & \\
\hline
\end{tabular}

* $F$ statistics and $P$ values are for main effects (year or species) and interactions (year $\times$ species) on mass-based photosynthesis $\left(P_{\max } /\right.$ mass), area-based net photosynthesis $\left(P_{\max } /\right.$ area), specific leaf area (SLA) and $\mathrm{N}$ concentration at Sites 1 and 2 , using groupings of species common in 2 or 3 yr. On Site 3 there were generally significant differences among species, but not among years, and there were no significant interactions (data not shown).

gressed from 1 to $9 \mathrm{yr}$ (across sites, Table 2). Mean daily PPFD at $1.5-1.7 \mathrm{~m}$ above the ground decreased more than one order of magnitude from years 1 to 9 with increasing vegetation stature and leaf area index. Average daily PPFD was similar for a 9-yr abandoned agricultural site and a treefall gap in the tierra firme forest (Table 2), although the temporal pattern of PPFD differed (data not shown).

\section{Leaf structure, nitrogen content, and photosynthesis}

On early successional sites recently abandoned from agriculture, we observed significant within-species relationships between $P_{\max }$ and leaf $\mathrm{N}$ concentration (Table 3). These relationships were stronger for massbased than for area-based parameters in all four successional species. Leaf phosphorus concentration was not correlated with $P_{\max }$ /mass in three species, and was

TABLE 2. Average daily and total daily integrated ( \pm 1 SE) photosynthetic photon flux density (PPFD) for successional and undisturbed forest sites near San Carlos de Río Negro, Venezuela. Data for each site are from three arbitrarily located sensors at 1.5-1.7 $\mathrm{m}$ above the ground on a predominately clear day, except for the primary forest site, where six sensors are averaged.

\begin{tabular}{ccc} 
& $\begin{array}{c}\text { Mean daily } \\
\text { PPFD } \\
(\mu \mathrm{mol} \cdot\end{array}$ \\
Successional stage & $\begin{array}{c}\text { Total daily PPFD } \\
\left(\mathrm{mol} \cdot \mathrm{m}^{-2} \cdot \mathrm{d}^{-1}\right)\end{array}$ \\
\hline 1 yr abandoned & 815 & $35.2 \pm 2.4$ \\
2 yr abandoned & 482 & $20.8 \pm 2.9$ \\
3 yr abandoned & 398 & $17.2 \pm 2.5$ \\
4 yr abandoned & 319 & $13.8 \pm 2.5$ \\
9 yr abandoned & 57 & $2.4 \pm 0.2$ \\
Treefall gap & 64 & $2.8 \pm 1.0$ \\
Primary forest & 33 & $1.4 \pm 0.3$ \\
\hline
\end{tabular}

weakly correlated in Vismia $\left(r^{2}=0.41, P<0.02\right.$, data not shown). Relationships between $P_{\max }$ /mass and SLA ( $r^{2}$ ranged from 0.16 to 0.55 ) were generally better than for $P_{\max }$ /area and SLA. SLA and $\mathrm{N}$ were correlated when $\mathrm{N}$ was expressed on a mass basis (in Vismia) and an area basis (in Cecropia) (Table 3).

The species-specific slope of the linear relationship between $P_{\max } /$ mass and percent $\mathrm{N}$ decreased with later species successional status (Cecropia $>$ Vismia $>$ Bellucia and Miconia; Table 3). Overall, however, there was still a strong relationship between $P_{\max } /$ mass and percent $\mathrm{N}$ for data pooled among species of early successional trees on sites ranging up to $5 \mathrm{yr}$ after abandonment $\left(r^{2}=0.61, P<0.0001\right.$, Fig. 3). On a given site, $P_{\max }$ expressed on a unit $\mathrm{N}$ basis $\left(P_{\max } / \mathrm{N}\right)$ decreased with later species successional status (Table 4) as did the slope of the $P_{\max }-\mathrm{N}$ relationship (Fig. 3). Trees on younger sites showed significantly higher $P_{\max } / \mathrm{N}(P<$ $0.05)$ than trees on the same site at a later successional stage (Table 4).

\section{Correlations among leaf traits along successional gradients}

In Vismia, mass-based photosynthesis-N $\left(r^{2}=0.74\right.$, $P<0.0001)$ and photosynthesis-SLA relationships $\left(r^{2}\right.$ $=0.58, P<0.0001$ ) were similar in slope to those in Table 3 when data from trees colonizing sites after other disturbance regimes (i.e., treefall gap and mechanized clearing) are included with data from postagricultural sites (Figs. 4a and 5a, respectively). In general, $P_{\max } /$ mass and percent $\mathrm{N}$ were greatest for individuals growing in the treefall gap and $1 \mathrm{st}-\mathrm{yr}$ abandoned agricultural site and lower for trees in older abandoned agricultural sites and the bulldozed site $(P<0.01$, Fig. 4$)$. Variation in SLA also followed this same general trend (Fig. 5). 
TABLE 3. Linear regression relationships between maximum photosynthetic rate $\left(P_{\max } /\right.$ mass or $P_{\max } /$ area), specific leaf area (SLA), and leaf $\mathrm{N}$ content (\% $\mathrm{N}$ or $\mathrm{N} / \mathrm{area}$ ) for leaves of four early to midsuccessional tree species growing in former agricultural sites up to 5 yr after abandonment near San Carlos de Río Negro, Venezuela.*

\begin{tabular}{|c|c|c|c|c|c|c|}
\hline Species & $\begin{array}{l}\text { Dependent } \\
\text { variable } †\end{array}$ & $\begin{array}{l}\text { Independent } \\
\text { variable }\end{array}$ & $r^{2}$ & $P$ & Slope & Intercept \\
\hline Cecropia & $P_{\max } /$ area & SLA & 0.09 & 0.011 & -0.055 & 22.616 \\
\hline Vismia & $P_{\max } /$ area & SLA & 0.12 & 0.0014 & 0.065 & 6.394 \\
\hline Bellucia & $P_{\mathrm{max}}$ /area & SLA & $\ldots$ & NS & $\ldots$ & $\ldots$ \\
\hline Miconia & $P_{\max }^{\operatorname{marea}}$ & SLA & $\cdots$ & NS & $\ldots$ & $\ldots$ \\
\hline Cecropia & $P_{\max } / \operatorname{mass}$ & SLA & $\ldots$ & NS & $\ldots$ & $\ldots$ \\
\hline Vismia & $P_{\max } /$ mass & SLA & 0.55 & 0.0001 & 2.065 & -76.169 \\
\hline Bellucia & $P_{\max } /$ mass & SLA & 0.41 & 0.0001 & 1.848 & -46.661 \\
\hline Miconia & $P_{\max } /$ mass & SLA & 0.16 & 0.0242 & 0.638 & 15.850 \\
\hline Cecropia & $P_{\max } /$ area & N/area & 0.40 & 0.0001 & 10.367 & -1.835 \\
\hline Vismia & $P_{\max } /$ area & N/area & 0.24 & 0.0001 & 5.572 & 4.206 \\
\hline Bellucia & $P_{\max } /$ area & N/area & $\cdots$ & NS & $\ldots$ & $\ldots$ \\
\hline Miconia & $P_{\max } /$ area & N/area & 0.24 & 0.0053 & 3.550 & 1.939 \\
\hline Cecropia & $P_{\max } /$ mass & $\% \mathrm{~N}$ & 0.57 & 0.0001 & 206.76 & -269.95 \\
\hline Vismia & $P_{\max }^{\max } / \operatorname{mass}$ & $\% \mathrm{~N}$ & 0.63 & 0.0001 & 115.55 & -48.55 \\
\hline Bellucia & $P_{\max } / \operatorname{mass}$ & $\% \mathrm{~N}$ & 0.14 & 0.0260 & 23.470 & 48.648 \\
\hline Miconia & $P_{\max } /$ mass & $\% \mathrm{~N}$ & 0.32 & 0.0009 & 42.162 & 3.492 \\
\hline Cecropia & N/area & SLA & 0.68 & 0.0001 & -0.009 & 2.960 \\
\hline Vismia & N/area & SLA & 0.09 & 0.0057 & -0.005 & 2.065 \\
\hline Bellucia & N/area & SLA & $\ldots$ & NS & ... & ... \\
\hline Miconia & N/area & SLA & 0.24 & 0.0050 & -0.0120 & 2.942 \\
\hline Cecropia & $\% \mathrm{~N}$ & SLA & $\ldots$ & NS & $\ldots$ & $\ldots$ \\
\hline Vismia & $\% \mathrm{~N}$ & SLA & 0.31 & 0.0001 & 0.011 & 0.496 \\
\hline Bellucia & $\% \mathrm{~N}$ & SLA & $\ldots$ & NS & $\ldots$ & $\ldots$ \\
\hline Miconia & $\% \mathrm{~N}$ & SLA & 0.13 & 0.0434 & 0.008 & 0.961 \\
\hline
\end{tabular}

* NS indicates relationships that are not statistically significant $(P>0.05)$ and thus no slopes or intercepts are presented. Sample size (leaves) for the analyses were: Cecropia, $n=68$; Vismia, $n=82$; Bellucia, $n=36$; and Miconia, $n=30$. Individuals of Licania were not present on any of these sites.

† Abbreviations and units as follows: $P_{\max } /$ area, area-based maximum net photosynthesis measured under ambient conditions at full sunlight, $\mu \mathrm{mol} \cdot \mathrm{m}^{-2} \cdot \mathrm{s}^{-1}, P_{\max } /$ mass, mass-based maximum net photosynthesis at full sunlight, $\mathrm{nmol} \cdot \mathrm{g}^{-1} \cdot \mathrm{s}^{-1}, \mathrm{~N} /$ area, leaf $\mathrm{N}$ content per unit area, $\mathrm{g} / \mathrm{m}^{2} ; \% \mathrm{~N}$, leaf $\mathrm{N}$ concentration as a percent of leaf dry mass; SLA, specific leaf area, $\mathrm{cm}^{2} / \mathrm{g}$.

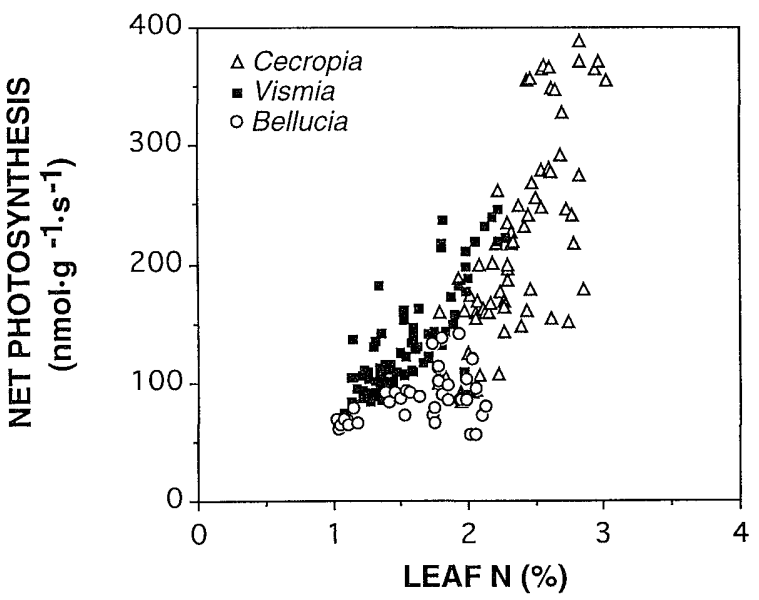

FIG. 3. Relationship between mass-based net photosynthesis $\left(P_{\max } /\right.$ mass) and leaf $\mathrm{N}$ concentration (leaf $\left.\mathrm{N}, \%\right)$ among three successional species on early successional slash-andburn sites (up to $5 \mathrm{yr}$ after abandonment). The overall linear relationship for the three species was $P_{\max } /$ mass $=-80.834$ +125.85 . leaf $\mathrm{N}\left(r^{2}=0.61, P<0.0001\right)$. Individual relationships for each species were also significant $(P<0.05)$ and are given in Table 3 .
TABle 4. $P_{\max } / \mathrm{N}$ for four successional species on two different slash-and-burn sites at 1, 3, and 5 yr after abandonment.* $P_{\max } / \mathrm{N}$ is expressed as the instantaneous rate of maximum net photosynthesis per unit leaf $\mathrm{N}$ concentration. $\uparrow$

\begin{tabular}{clcc}
\hline \hline \multirow{2}{*}{$\begin{array}{c}\text { Years } \\
\text { abandoned }\end{array}$} & \multicolumn{2}{c}{$P_{\max } / \mathrm{N}$} \\
\cline { 3 - 4 } 1 & Species & $\bar{X}$ & SE \\
\hline \multirow{2}{*}{1} & Site 1 & \\
& Cecropia & $186.3^{\mathrm{a}}$ & 3.9 \\
& Vismia & $144.7^{\mathrm{b}}$ & 5.3 \\
\multirow{3}{*}{3} & Bellucia & $93.8^{\mathrm{d}}$ & 4.6 \\
& Cecropia & $121.4^{\mathrm{c}}$ & 9.5 \\
& Vismia & $101.3^{\mathrm{d}}$ & 2.7 \\
& Bellucia & $88.0^{\mathrm{d}}$ & 6.0 \\
& & & \\
\multirow{2}{*}{3} & Cecropia & $141.8^{\mathrm{a}}$ & 5.4 \\
& Vismia & $129.5^{\mathrm{a}}$ & 6.8 \\
& Bellucia & $81.7^{\mathrm{bc}}$ & 3.4 \\
& Miconia & $71.3^{\mathrm{cd}}$ & 3.0 \\
5 & Vismia & $95.8^{\mathrm{b}}$ & 5.4 \\
& Bellucia & $68.5^{\mathrm{cd}}$ & 3.7 \\
& Miconia & $61.3^{\mathrm{d}}$ & 4.8 \\
\hline
\end{tabular}

* Data shown are means \pm 1 SE. Within a site (column), means followed by different letters are significantly different $(P<0.05)$ using Bonferroni significant differences.

$\dagger$ Units for $P_{\max } / \mathrm{N}$ are $\mu \mathrm{mol} \mathrm{CO} \mathrm{CO}_{2} \cdot[\mathrm{mol} \mathrm{N}]^{-1} \cdot \mathrm{s}^{-1}$. 

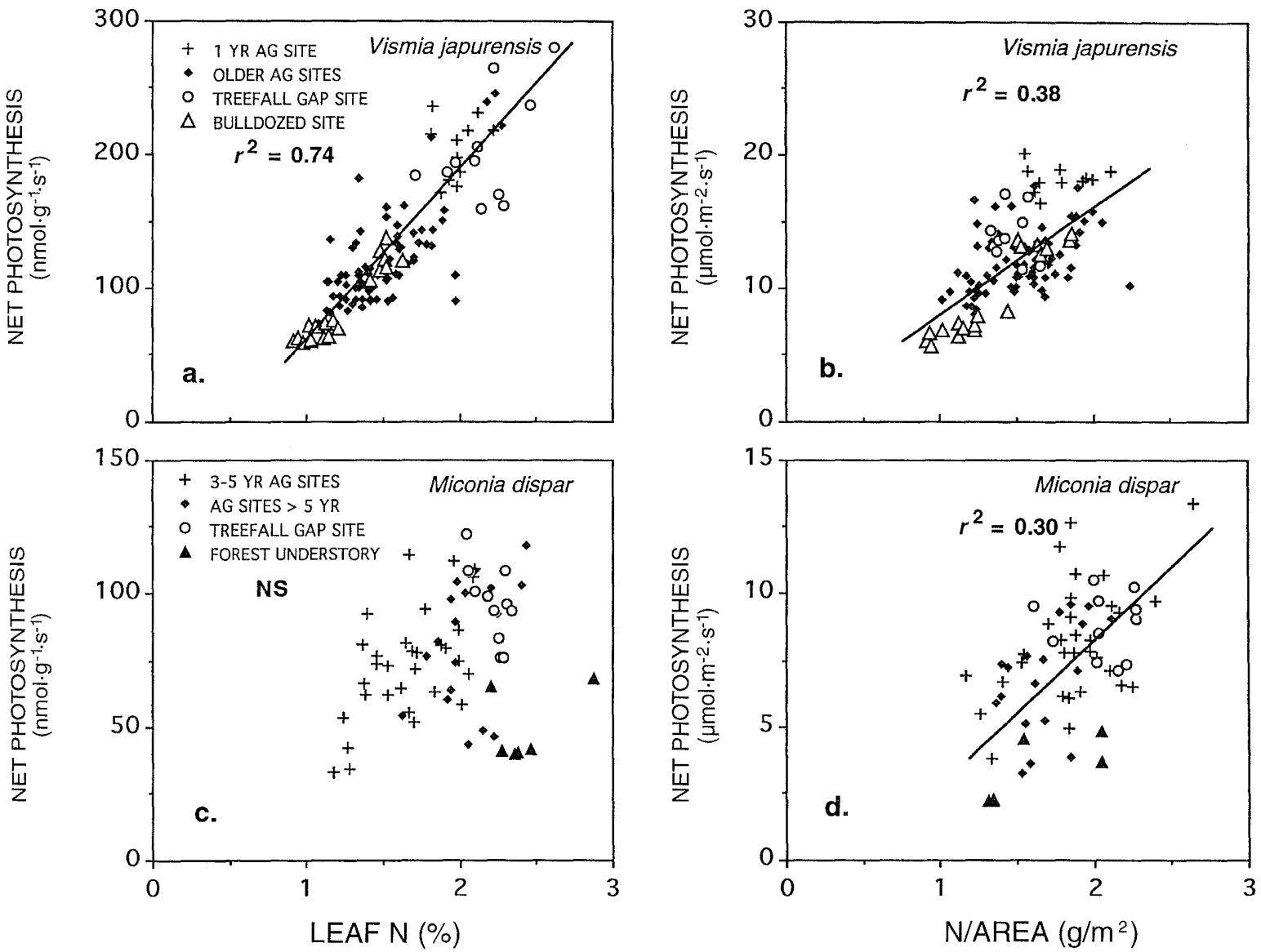

FIG. 4. Regression relationship between (a) mass-based net photosynthesis $\left(P_{\max } /\right.$ mass) and leaf $\mathrm{N}$ concentration (leaf N) and (b) area-based net photosynthesis $\left(P_{\max } /\right.$ area) and area-based leaf $\mathrm{N}$ content (N/area) for Vismia growing across a successional sere on postagricultural sites and a disturbance intensity gradient from natural treefall to slash-and-burn sites to a bulldozed site. Sites are $1 \mathrm{yr}$ after abandonment from slash-and-burn agriculture (1 yr ag site), 2-5 yr after abandonment from agriculture (older ag sites), a tierra firme treefall gap (treefall gap site), and a site that had been bulldozed 10 yr prior to measurement (bulldozed site). The relationships shown are $P_{\max } /$ mass $=-53.3+118.0 \cdot \operatorname{leaf} \mathrm{N}\left(r^{2}=0.74, P<0.0001\right)$ and $P_{\max }$ /area $=1.50+7.19 \cdot \mathrm{N} /$ area $\left(r^{2}=0.38, P<0.0001\right)$. (c, d) Regression relationship between (c) mass-based net photosynthesis $\left(P_{\max } /\right.$ mass) and leaf $\mathrm{N}$ concentration (leaf $\left.\mathrm{N}\right)$ and $(\mathrm{d})$ area-based net photosynthesis $\left(P_{\mathrm{max}} /\right.$ area) and area-based leaf $\mathrm{N}$ content (N/area) for Miconia. The axis scale for Miconia is half of that shown for Vismia. Sites are 3-5 yr abandonment from slash-and-burn agriculture (3-5 yr ag sites), 9-10 yr after abandonment from agriculture (ag sites $>5 \mathrm{yr}$ ), a tierra firme treefall gap (treefall gap site), and in the understory of an undisturbed tierra firme forest (forest understory). The relationships shown are not significant (NS, $P>0.10)$ and $P_{\max } /$ area $=-0.41+4.32 \cdot$ N/area $\left(r^{2}=0.30, P<0.0001\right)$.

Across broad site variation, relationships in Vismia between area-based photosynthesis and $\mathrm{N}$ or SLA were poorer $\left(r^{2}=0.38\right.$ and 0.10 , Figs. $4 \mathrm{~b}$ and $5 \mathrm{~b}$, respectively) than mass-based ones.

Miconia, on the other hand, had a significant areabased $P_{\max }-\mathrm{N}$ relationship $(P<0.0001)$ but not massbased $P_{\max }-\mathrm{N}$ relationship $(P>0.05)$ when data from a treefall gap and more deeply shaded, later successional sites are included with data from early successional sites (Fig. 4d). Also contrasting with Vismia, there was a significant negative correlation between $P_{\max }$ /area and SLA $\left(P<0.0001\right.$, Fig. 5 d), whereas the $P_{\max } /$ mass-SLA relationship was not significant (Fig. 5c).

\section{DisCUSSION}

Early successional species had higher $P_{\max }$ than later successional species on both an area and mass basis when species are compared on sites where they are most abundant (e.g., compare Cecropia at 1 yr after abandonment, Vismia at 2-3 yr, and Miconia at 9-10 yr). These results support earlier hypotheses concerning differences in $P_{\max }$ vis-à-vis species successional status (Bazzaz 1979, Bazzaz and Pickett 1980) and are consistent with a more limited survey of 13 tierra firme species (Reich et al. 1995). However in earlier studies it was not possible to distinguish between species differences and differences in successional stage as the cause of such a pattern because early and late successional species have frequently been measured on different sites at different successional stages (cf. Riddoch et al. 1991, Reich et al. 1995). To address this issue we should compare co-occurring species on common sites across a range of successional stages, as in the current study. 

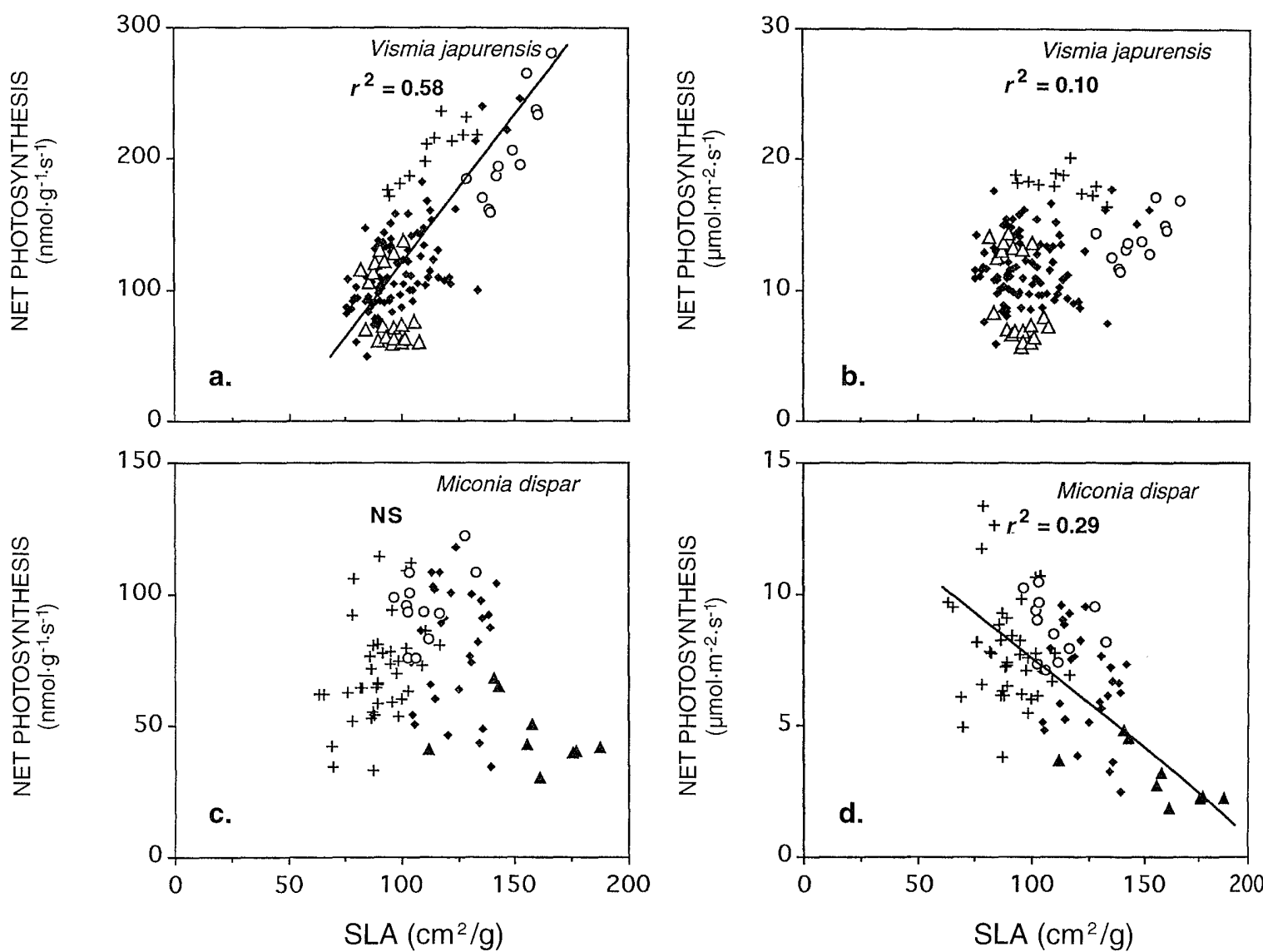

FIG. 5. Relationship among $P_{\max } /$ mass, $P_{\max } /$ area, and specific leaf area (SLA) for Vismia. Legend as in Fig. 4a. The relationships shown are $P_{\max } /$ mass $=-68.6+1.92 \cdot \mathrm{SLA}\left(r^{2}=0.58, P<0.0001\right)$ and $P_{\max } /$ area $=7.04+0.05 \cdot \mathrm{SLA}\left(r^{2}=\right.$ $0.10, P<0.001$ ). (c, d) Relationship among $P_{\max } /$ mass, $P_{\max } /$ area, and specific leaf area (SLA) for Miconia. The axis scale for Miconia is half of that shown for Vismia. Legend as in Fig. 4c. The relationships shown are not significant (NS, $P>$ $0.20)$ and $P_{\max } /$ area $=13.14+0.05 \cdot$ SLA $\left(r^{2}=0.29, P<0.0001\right)$.

Among species co-occurring in the same successional habitat, early successional species such as $\mathrm{Cec}$ ropia and Vismia generally had higher $P_{\text {max }} /$ mass (and to a lesser extent, $P_{\max } /$ area) than later successional species Bellucia and Miconia, and these differences were much greater sooner following abandonment (e.g., 1 yr) than later (Figs. 1 and 2). Photosynthetic rates also generally decreased in all species with time during succession, suggesting that both species composition and temporal patterns (i.e., patterns in resource availability) together contribute to the strong decrease in leaf photosynthesis observed during early secondary succession. While the chronosequence approach taken in this study did not incorporate true replicate chronosequences on different sites starting at the same point in succession (Pickett 1989), the consistency of trends over 3 yr on the two earlier successional sites (Sites 1 and 2) does suggest commonality of these decreases with increasing time since abandonment from slashand-burn agriculture (up to $5 \mathrm{yr}$ ) in the upper Río Negro region.

Comparisons of species on common sites may also indicate that there are intrinsic species differences in photosynthetic capacity among species with different successional status (Bazzaz 1979), although other factors such as favorable microhabitat occupation of early colonizing species and intrinsic species differences in nutrient uptake capacities and allocation to roots vs. shoots (Walters et al. 1993) may also indirectly influence patterns in species photosynthetic capacity on a given site. For instance, pre-emptive use of resources by pioneer species may in part explain why the pioneer species Cecropia has higher leaf $\mathrm{N}$ than co-occurring species and may also have an important bearing on habitat resource availability for later colonizing species (Uhl 1987).

\section{Photosynthesis and resource theory}

Leaf photosynthetic characteristics may be considered in the broader context of plant growth and resource utilization in order to make inferences about species ecophysiological strategies in early secondary succession. Arguments based on species intrinsic growth rate differences and resource limitation theory suggest that 
early successional species will predominate in resource-rich environments where high resource supply rates are capable of supporting species with high resource acquisition rates, high leaf nutrient contents, high rates of photosynthesis and respiration, short leaf lifetimes, and rapid height and whole-plant growth (Bazzaz 1979, Chapin 1980, Reich et al. 1992, 1995). The species Cecropia and Vismia show a suite of characteristics typical of such species on early successional sites including high leaf $\mathrm{N}$ concentration early in succession and high $P_{\max }$ /mass (Fig. 2), and thin leaves (high SLA, Fig. 1), short leaf life-span (Uhl 1987 , Reich et al. 1995), and rapid growth (Uhl 1987; D. S. Ellsworth and P. B. Reich, unpublished data) that are generally consistent with these ideas.

However as secondary succession progresses on a site, there is a general trend toward decreasing photosynthetic capacity (on an area and mass basis) both within and among species (Figs. 1 and 2). In particular, early successional species (e.g., Cecropia and Vismia) show decreases in photosynthetic capacity and leaf $\mathrm{N}$ concentration with increasing time (Figs. 1 and 2), indicating possible plant senescence and/or increasing resource limitations during early succession. The lack of strong differences in $P_{\max }$ (area and mass based), leaf $\mathrm{N}$ concentration, and SLA between different species at 5 yr after abandonment (Figs. 1 and 2) supports such an argument. Still, leaf photosynthetic capacity and plant carbon balance must be viewed along with other factors that may contribute to species dynamics in succession, including seed rain and germination, seedling recruitment patterns, canopy architecture, and wholeplant carbon allocation patterns, species life history traits, and susceptibility to herbivory and disease (Bazzaz and Pickett 1980, Pickett et al. 1987, Uhl 1987, Givnish 1988, Walters et al. 1993).

On early successional sites, individuals may have high leaf $\mathrm{N}$ concentration when $\mathrm{N}$ supply is high following slash-and-burn agriculture and uptake demand is low due to low vegetation density (Vitousek and Walker 1987). Although leaf $N$ concentration is not always a good indicator of $\mathrm{N}$ availability because of different patterns in $N$ uptake among species (Chapin 1980, Vitousek et al. 1989), similar trends toward decreases in leaf $\mathrm{N}$ within species during early succession (Fig. 2) could indicate a common response of species to overall site $\mathrm{N}$ availability.

Interpretations of the observed successional patterns are based in part on the assumption that resource availability (e.g., light and nutrient availability) is high early in and then decreases later in secondary succession. Clearly light availability is high soon after abandonment when the site is sparsely vegetated following short-term agriculture and then declines as revegetation occurs (Table 2). Patterns of $\mathrm{N}$ availability during succession are more complex, and observations of both increasing or decreasing $\mathrm{N}$ availability through secondary succession have been made (reviewed in Vitousek et al. 1989). In both temperate and tropical ecosystems, however, a large $\mathrm{N}$ release from organic matter following forest cutting (Vitousek et al. 1982) or cutting and burning (Ewel et al. 1981, Uhl and Jordan 1984, Matson et al. 1987) has been well documented. An extended period of agriculture or topsoil removal can result in depletion of soil $\mathrm{N}$ and organic matter, giving rise to observations of low $\mathrm{N}$ after abandonment in some systems (Tilman 1988, Vitousek et al. 1989). In the Upper Río Negro region, however, previous studies have shown elevated $\mathrm{N}$ mineralization in recently abandoned agricultural sites which had been cut, burned and farmed similarly to those used in this study compared to mineralization rates in nearby tierra firme forest (Montagnini and Buschbacher 1989). Moreover, $\mathrm{N}$ release from decomposition of residual forest and agricultural slash may also continue after abandonment (Uhl 1987). In sum, evidence from these studies indicates that the early successional sequence after short-term agricultural use on tierra firme soils can likely be considered a gradient from high light and $\mathrm{N}$ availability at the time of site abandonment to relatively low availability of these resources after $5 \mathrm{yr}$ of succession. Decreases in resource availability may be particularly relevant to species successional dynamics after slash-and-burn agriculture because of differences in resource-use patterns in successional species (Chapin 1983, Uhl 1987).

\section{Photosynthesis $-N$ relationships in successional trees}

Relatively few tropical successional studies have analyzed the role of variation in leaf nutrition in species plasticity through succession. Among different species, including Amazonian trees, photosynthetic capacity is well correlated with leaf $\mathrm{N}$ because of the importance of $\mathrm{N}$-containing proteins in carbon assimilation and metabolism (Field and Mooney 1986, Evans 1989, Reich et al. 1991). Within species, leaf $\mathrm{N}$ has been correlated with photosynthetic capacity in successional rain forest Piper species in Mexico (Chazdon and Field 1987, Walters and Field 1987), although there were no such correlations in species restricted to mature rain forest sites. For species on early successional sites, flexibility in leaf photosynthetic capabilities $\left(P_{\max }\right.$ ' mass) are correlated with leaf $\mathrm{N}$ concentration in Amazonian trees as well (Table 3, Fig. 3; Reich et al. 1994).

We found a strong trend toward a decreasing slope of the relationship between $P_{\max } /$ mass and leaf $\mathrm{N}$ for species with later successional status (Fig. 3, Table 3). This pattern mirrors that for a larger survey of species (including the five in this study) in the northern Amazon basin (Reich et al. 1994), despite distinct differences in sources of variation in leaf $\mathrm{N}$ and $P_{\max }$ among the studies. In the current study, variation was observed among leaves of comparable physiological age and light environment (sun leaves) but on different trees over 2-3 yr of succession among different sites. In the previous study (Reich et al. 1994), variation was a result of sampling diverse leaf ages and light microen- 
vironments within given site/successional stages. The similarity of results (decreasing slope of $P_{\max }$ to $\mathrm{N}$ with later successional status) suggests that this is a common pattern in tropical tree species despite different sources of variation in leaf characteristics.

Also, as a result of species differences in the slope and intercept of the $P_{\max }-\mathrm{N}$ relationship, $P_{\max } / \mathrm{N}$ is generally higher for early than for later successional species on the same site (Table 3), indicating that these species can sustain a higher photosynthetic capacity ( $P_{\max } /$ mass) per unit $\mathrm{N}$ in a leaf. At lower leaf $\mathrm{N}$ levels, all species have roughly similar $P_{\max } /$ mass, corroborating the observed trend toward similar $P_{\max } /$ mass later in succession when species have similar leaf $N$ (for example at $4-5 \mathrm{yr}$ after abandonment, Fig. 2). Thus, high $P_{\max } / \mathrm{N}$ may confer a competitive, carbon gain advantage to early successional species when $\mathrm{N}$ availability is high in early secondary succession on tierra firme (Reich et al. 1995).

Why does $P_{\max } / \mathrm{N}$ differ between early and late successional species? Field and Mooney (1986) suggested that (1) the fraction of leaf $\mathrm{N}$ allocated to the photosynthetic apparatus may vary among species and (2) there may be species differences in the minimum $\mathrm{N}$ and SLA required for the construction of a leaf that can attain positive photosynthetic rates. These two possibilities are not mutually exclusive, but rather may arise from the linear nature of photosynthesis $-\mathrm{N}$ relationships (Field and Mooney 1986). Evans (1989) showed that shade-adapted, late successional species allocate a higher fraction of leaf $\mathrm{N}$ to light-harvesting pigments and protein complexes that are not directly involved in dark reactions of photosynthesis than do crops and early successional herbs grown under roughly similar environmental conditions.

\section{Plasticity in leaf traits in species of contrasting successional status}

Most comparative studies of plasticity among species characterized by different successional niches have been carried out on potted seedlings grown for several months in different light environments (Bazzaz and Carlson 1982, Oberbauer and Strain 1984, Strauss-Debenedetti and Bazzaz 1991). However, variability in both light and nutrients across successional gradients may together determine the magnitude and type of plasticity observed (Thompson et al. 1988). The question of whether early successional species differ in plasticity of leaf traits compared to later successional species may depend to a large degree upon which specific traits are examined, since some species showed greatest plasticity in mass-based $P_{\max }$ (Vismia) while others varied more in area-based $P_{\max }$ (Miconia). The early successional species Vismia showed a similar degree of plasticity in areabased $P_{\max }$ (approximately fourfold) as did the midsuccessional species Miconia across the successional gradients in which it occurs, suggesting that both species have considerable capacity to alter physiological traits in changing successional habitats. Differences in plasticity may be greater when species representing even greater successional extremes are compared.

In both Vismia and Miconia, directional shifts in leaf $\mathrm{N}$ were observed across successional gradients which may reflect resource levels in habitats ranging from a degraded, bulldozed site to postagricultural sites to intact tierra firme forest treefall gaps and understory (Figs. 4 and 5). Differences in the magnitude of plasticity in intrinsic photosynthetic capacity in an early and mid-successional species (compare Vismia, Fig. 4a and Miconia, Fig. 4c) may in part be related to the differences in photosynthetic gain per unit $\mathrm{N}$ as discussed earlier.

Variation in both light and $\mathrm{N}$ availability among different habitats does not appear to affect the relationships among $P_{\max }, \mathrm{N}$, and SLA in Vismia that were observed in Figs. 4 and 5 compared to data for abandoned agricultural sites only (compare Table 3 to Figs. 4a and 5a). Thus variation in $P_{\max }, \mathrm{N}$, and SLA in Vismia appears to be consistent with trends in resource availability among sites differing in disturbance intensity (natural treefalls vs. mechanized clearing) and time since abandonment from an intermediate disturbance (slash-and-burn agriculture). Without experimental manipulation it is not possible to separate effects of light and $\mathrm{N}$ availability on leaf characteristics in Vismia. However, similar $P_{\max }$ /mass and $\mathrm{N}$ concentration were observed in trees in habitats with high and low light availability (1-yr abandoned agricultural sites and gap sites), whereas trees in high light habitats differing in soil disturbance intensity showed different $P_{\max } /$ mass and $\mathrm{N}$ concentration (compare Vismia in abandoned agricultural vs. bulldozed sites).

The trend toward increasing leaf $\mathrm{N}$ concentration with increasing successional stage from younger-toolder abandoned agricultural sites to tierra firme understory observed for Miconia (Fig. 4c) runs counter to what might be predicted on the basis of general successional trends in nutrient availability (Vitousek and Walker 1987, Ewel et al. 1991). However, this pattern inversely parallels differences in SLA across these sites: SLA is highest in the shaded forest understory and lowest in the youngest successional sites on which Miconia occurs. Thus the greater leaf $\mathrm{N}$ concentration in Miconia in late successional habitats is associated with lower SLA (Fig. 5d) and higher N/area (Fig. 4d), which suggests a dilution of leaf $\mathrm{N}$ concentration and increased leaf carbon/nitrogen ratio in early successional habitats where light is less limiting.

Previous studies have shown that leaves produced in response to nutrient limitation have lower SLA (thicker leaves), but SLA also decreases in response to increases in integrated light levels (Björkman 1981, Thompson et al. 1988, Ellsworth and Reich 1992). In successional environments, variation in resource availability (e.g., light and $\mathrm{N}$ availability in this study) may thus have different effects on leaf characteristics such as leaf $\mathrm{N}$ 
and SLA (Figs. 4 and 5). Because decreases in SLA may dilute leaf $\mathrm{N}$ concentration (Table 3), even when $\mathrm{N}$ availability is similar between habitats, changes in light availability may result in variation in leaf photosynthetic characteristics and $\mathrm{N}$ content. This appears to be the case in Miconia, where understory leaves with the highest SLA also show the highest $N$ concentration but the lowest $P_{\max } /$ mass and $P_{\max } /$ area (see Evans 1989). Low $P_{\max }$ in shaded, understory leaves has generally been interpreted as an adaptive feature of plants common in understory habitats that cannot support high metabolic costs of maintaining high photosynthetic capacity in the shade (Björkman 1981, Givnish 1988). On the other hand, because of its fast height growth rate in early successional habitats (Uhl 1987), Vismia may maintain a large proportion of foliage in relatively high light microsites.

The patterns in photosynthesis- $\mathrm{N}$ relationships that were observed for Vismia and Miconia across broad habitat gradients are consistent with those observed for sun- and shade-adapted Piper species in a Mexican rain forest (Chazdon and Field 1987). In that study, photosynthesis- $\mathrm{N}$ relationships showed better fits when these variables were expressed on a mass basis for species common in large treefall gaps and disturbed habitats, whereas species persisting into closed forest habitats showed either no such relationships on an area nor mass basis, or better goodness of fit for area-based photosynthesis- $\mathrm{N}$ relationships than for the corresponding mass-based relationships. Based on our data we predict that pioneer and early successional species colonizing sites soon after abandonment will show strong mass-based photosynthesis- $\mathrm{N}$ relationships across successional seres and will also show greater photosynthetic rates with increased nutrient availability soon after disturbance compared to rates exhibited longer after disturbance (Fig. 3; also see Reich et al. 1994). More persistent later successional species that are slower growing and occupy more shaded habitats, in contrast, may show significant area-based relationships between photosynthesis and N, largely because of variation in SLA and hence $\mathrm{N}$ per area among habitats with variability in light availability in the later successional habitats (Ellsworth and Reich 1992). Although species' successional strategies may vary continuously from pioneer to early, mid and late successional, the constraints of changing resource availability early in tropical secondary succession (1-5 yr after abandonment) may especially favor selection for high plasticity in leaf photosynthetic traits at that time.

\section{ACKNOWLEDGMENTS}

This research was funded in part by N.S.F grants BSR889718 and BSR-8857129 to the authors and travel grants from the Nave Foundation and the University of Wisconsin to D.S.E. We thank Mike Walters for going to San Carlos with us under less-than-optimal conditions and for providing many useful discussions and comments during the field work and preparation of this paper. We are grateful to Dionisio
Gómez for assistance in the field, and the Centro de Ecología, I.V.I.C., for logistic support during visits to Caracas. A previous version of the manuscript was substantially improved by comments from two anonymous reviewers. Finally, many thanks to Pedro Maquirino for technical assistance in the field and to P.M. and Chris Uhl for teaching us about the ecology of the San Carlos de Río Negro region.

\section{Literature Cited}

Bazzaz, F. A. 1979. The physiological ecology of plant succession. Annual Review of Ecology and Systematics 10: 351-371.

Bazzaz, F. A., and R. W. Carlson. 1982. Photosynthetic acclimation to variability in the light environment of early and late successional plants. Oecologia 54:313-316.

Bazzaz, F. A., and S. T. A. Pickett. 1980. Physiological ecology of tropical succession: a comparative review. Annual Review of Ecology and Systematics 11:287-310.

Björkman, O. 1981. Responses to different quantum flux densities. Pages 57-107 in O. L. Lange, P. S. Nobel, C. B. Osmond, and H. Ziegler, editors. Encyclopedia of plant physiology. New Series. Volume 12A. Springer-Verlag, New York, New York, USA.

Brown, S., and A. E. Lugo. 1990. Tropical secondary forests. Journal of Tropical Ecology 6:1-32.

Chapin, F. S., III. 1980. The mineral nutrition of wild plants. Annual Review of Ecology and Systematics 13:229-259.

- 1983. Patterns of nutrient absorption and use by plants from natural and man-modified environments. Pages 175-187 in H. A. Mooney and M. Godron, editors. Disturbance and ecosystems: components of response. Springer-Verlag, New York, New York, USA.

Chapin, F. S., A. J. Bloom, C. B. Field, and R. H. Waring. 1987. Plant responses to multiple environmental factors. BioScience 37:49-57.

Chazdon, R. L. 1992. Photosynthetic plasticity of two rainforest shrubs across natural gap transects. Oecologia 92: 586-595.

Chazdon, R. L., and C. B. Field. 1987. Determinants of photosynthetic capacity in six rainforest Piper species. Oecologia 73:222-230.

Chazdon, R. L., and S. Kaufmann. 1993. Plasticity of leaf anatomy of two rain forest shrubs in relation to photosynthetic light acclimation. Functional Ecology 7:385-394.

Clark, D. A., and D. B. Clark. 1992. Life history diversity of canopy and emergent trees in a neotropical rain forest. Ecological Monographs 62:315-344.

Clark, K., and C. Uhl. 1987. Farming, fishing, and fire in the history of the Upper Río Negro region of Venezuela. Human Ecology 15:1-26.

Cooper, W. S. 1926. The fundamentals of vegetational change. Ecology 7:391-413.

Ellsworth, D. S., and P. B. Reich. 1992. Leaf mass per area, nitrogen content, and photosynthetic carbon gain in Acer saccharum seedlings in contrasting forest light environments. Functional Ecology 6:423-435.

Evans, J. R. 1989. Photosynthesis and nitrogen relationships in leaves of $\mathrm{C}_{3}$ plants. Oecologia 78:9-19.

Ewel, J., C. Berish, and C. Berish. 1991. Tropical soil fertility changes under monocultures and successional communities of different structure. Ecological Applications 1: 289-302.

Ewel, J., M. Mazzarino, B. Brown, N. Price, and J. Raich. 1981. Slash and burn impacts on a Costa Rican wet forest site. Ecology 62:816-829.

Field, C., and H. A. Mooney. 1986. The photosynthesisnitrogen relationship in wild plants. Pages $25-55$ in $\mathrm{T}$. Givnish, editor. On the economy of plant form and function. Cambridge University Press, Cambridge, England.

Fittkau, E.-J., W. Junk, H. Klinge, and H. Sioli. 1975. Substrate and vegetation in the Amazon region. Pages 70-93 
in H. Dierschke, editor. Vegetation und substrat. Berichte der Internationalen Vereinungung für Vegetationskunde. A. R. Gantner Verlag, Vaduz, Liechtenstein.

Givnish, T. J. 1988. Adaptation to sun and shade: a wholeplant perspective. Australian Journal of Plant Physiology 15:63-92.

Herrera, R., C. Jordan, H. Klinge, and E. Medina. 1978. Amazon ecosystems: Their structure and functioning with particular emphasis on nutrients. Interciencia 3:223-231.

Houghton, R. A., D. S. Lefkowitz, and D. L. Skole. 1991. Changes in the landscape of Latin America between 1850 and 1985. I. Progressive loss of forests. Forest Ecology and Management 38:143-172.

Huston, M., and T. Smith. 1987. Plant succession: life history and competition. American Naturalist 130:168-198.

Matson, P. A., P. M. Vitousek, J. J. Ewel, M. J. Mazzarino, and G. P. Robertson. 1987. Nitrogen transformations following tropical forest felling and burning on a volcanic soil. Ecology 68:491-502.

Medina, E., and E. Cuevas. 1989. Patterns of nutrient accumulation and release in Amazonian forests of the upper Río Negro basin. Pages 217-240 in J. Proctor, editor. Mineral nutrients in tropical forest and savanna ecosystems. Blackwell Scientific, Oxford, England.

Montagnini, F, and R. Buschbacher. 1989. Nitrification rates in two undisturbed tropical rain forests and three slash-andburn sites of the Venezuelan Amazon. Biotropica 21:9-14.

Mooney, H. A., C. B. Field, and C. Vázquez-Yánes. 1984. Photosynthetic characteristics of wet tropical forest plants. Pages 113-128 in E. Medina, H. A. Mooney, and C. Vázquez-Yánes, editors. Physiological ecology of plants of the wet tropics. Dr. W. Junk, The Hague, The Netherlands.

Oberbauer, S. F., and B. R. Strain. 1984. Photosynthesis and successional status of Costa Rican rain forest trees. Photosynthesis Research 5:227-232.

Pearcy, R. W. 1988. Photosynthetic utilization of lightflecks by understory plants. Australian Journal of Plant Physiology 15:223-238.

Pickett, S. T. A. 1989. Space-for-time substitution as an alternative to long-term studies. Pages 110-135 in G. Likens, editor. Long-term studies in ecology: approaches and alternatives. Springer-Verlag, New York, New York, USA.

Pickett, S. T. A., S. L. Collins, and J. J. Armesto. 1987. Models, mechanisms and pathways of succession. Botanical Review 53:335-371.

Reich, P. B., D. S. Ellsworth, and C. Uhl. 1995. Leaf carbon and nutrient assimilation and conservation in species of differing successional status in an oligotrophic Amazonian forest. Functional Ecology 9:65-76.

Reich, P. B., C. Uhl, M. B. Walters, and D. S. Ellsworth. 1991. Leaf lifespan as a determinant of leaf structure and function among 23 Amazonian tree species. Oecologia 86: 16-24.

Reich, P. B., M. B. Walters, and D. S. Ellsworth. 1992. Leaf life-span in relation to leaf, plant and stand characteristics among diverse ecosystems. Ecological Monographs 62: 365-392.

Reich, P. B., M. B. Walters, D. S. Ellsworth, and C. Uhl. 1994. Photosynthesis-nitrogen relations in Amazonian tree species. I. Patterns among species and communities. Oecologia 97:62-72.

Riddoch, I., J. Grace, F. E. Fasehun, B. Riddoch, and D. O. Ladipo. 1991. Photosynthesis and successional status of seedlings in a tropical semi-deciduous rain forest in $\mathrm{Ni}$ geria. Journal of Ecology 79:491-503.

SAS. 1994. JMP statistics and graphics guide. Version 3. SAS Institute, Cary, North Carolina, USA.

Schulze, E.-D., and F. S. Chapin, III. 1987. Plant special- ization to environments of different resource availability. Pages 120-148 in E.-D. Schulze and H. Zwölfer, editors. Potentials and Limitations of Ecosystem Analysis. Springer-Verlag, Berlin, Germany.

Steel, R. G. D., and J. H. Torrie. 1980. Principles and procedures of statistics. Second edition. McGraw Hill, New York, New York, USA.

Strauss-Debenedetti, S., and F. A. Bazzaz. 1991. Plasticity and acclimation to light in tropical Moraceae of different successional positions. Oecologia 87:377-387.

Thompson, W. A., L.-K. Huang, and P. E. Kriedemann. 1992. Photosynthetic response to light and nutrients in sun-tolerant and shade-tolerant rainforest trees. II. Leaf gas exchange and component processes of photosynthesis. Australian Journal of Plant Physiology 19:19-42.

Thompson, W. A., G. C. Stocker, and P. E. Kriedemann. 1988. Growth and photosynthetic response to light and nutrients of Flindersia brayleyana F. Muell., a rainforest tree with broad tolerance to sun and shade. Australian Journal of Plant Physiology 15:299-315.

Tilman, D. 1988. Plant strategies and the dynamics and structure of plant communities. Princeton University Press, Princeton, New Jersey, USA.

Tilman, D., and D. Wedin. 1991. Plant traits and resource reduction for five grasses growing on a nitrogen gradient. Ecology 72:685-700.

Uhl, C. 1987. Factors controlling succession following slashand-burn agriculture in Amazonia. Journal of Ecology 75: $377-407$.

Uhl, C., H. Clark, K. Clark, and P. Maquirino. 1982a. Successional patterns associated with slash-and-burn agriculture in the Upper Río Negro region of the Amazon Basin. Biotropica 14:249-254.

Uhl, C., K. Clark, N. Dezzeo, and P. Maquirino. 1988. Vegetation dynamics in Amazonian treefall gaps. Ecology 69: $751-763$

Uhl, C., and C. F. Jordan. 1984. Succession and nutrient dynamics following forest cutting and burning in Amazonia. Ecology 65:1476-1490.

Uhl, C., C. F. Jordan, K. Clark, H. Clark, and R. Herrera. 1982b. Ecosystem recovery in Amazon caatinga forest after cutting, burning, and bulldozer clearing treatments. Oikos 38:313-320.

Vitousek, P. M., and J. S. Denslow. 1987. Nitrogen and phosphorus availability in treefall gaps of a lowland tropical rainforest. Journal of Ecology 74:1167-1178.

Vitousek, P. M., J. R. Gosz, C. C. Grier, J. M. Melillo, and W. A. Reiners. 1982. A comparative analysis of potential nitrification and nitrate mobility in forest ecosystems. Ecological Monographs 52:155-177.

Vitousek, P. M., P. A. Matson, and K. van Cleve. 1989. Nitrogen availability and nitrification during succession: primary, secondary, and old-field seres. Pages 161-171 in M. Clarholm and L. Bergström, editors. Ecology of arable land. Kluwer Academic, Amsterdam, The Netherlands.

Vitousek, P. M., and L. R. Walker. 1987. Colonization, succession and resource availability: ecosystem-level interactions. Pages 207-223 in A. J. Gray, M. J. Crawley, and P. J. Edwards, editors. Colonization, succession and stability. Blackwell Scientific, Oxford, England.

Walters, M. B., and C. B. Field. 1987. Photosynthetic light acclimation in two rainforest Piper species with different ecological amplitudes. Oecologia 72:449-456.

Walters, M. B., E. L. Kruger, and P. B. Reich. 1993. Growth, biomass distribution and $\mathrm{CO}_{2}$ exchange of northern hardwood seedlings in high and low light: relationships with successional status and shade tolerance. Oecologia 94:716. 